\title{
Enhancing Competitiveness through Compliance: Case of Technology Compliance
}

\author{
Tamanna Chaturvedi, O. P. Wali, Ankit Kesharwani* \\ Department of Trade, Indian Institute of Foreign Trade, New Delhi, India \\ Email: *ankit@iift.edu
}

How to cite this paper: Chaturvedi, T., Wali, O.P. and Kesharwani, A. (2019) Enhancing Competitiveness through Compliance: Case of Technology Compliance. Theoretical Economics Letters, 9, 2397-2417. https://doi.org/10.4236/tel.2019.97152

Received: May 22, 2019

Accepted: September 27, 2019

Published: September 30, 2019

Copyright $\odot 2019$ by author(s) and Scientific Research Publishing Inc. This work is licensed under the Creative Commons Attribution International License (CC BY 4.0).

http://creativecommons.org/licenses/by/4.0/

(c) (i) Open Access

\begin{abstract}
Role of technology towards promoting innovations and enhancing competitiveness is very well witnessed. However, this perspective can only remain sustainable in light of stringent IPR protection which becomes essential towards ensuring sustainable competitiveness in light of the growing incidence of noncompliance in the form of digital piracy prevalent globally. The international pricing and competitiveness of goods with the use of pirated software completely distorts the market which goes against the basic international trade theory which assumes the absence of distortions in the prices of factors of production when the trading countries entered into trade only due to the commodity price differences between themselves. Taking cognizance of such a situation some states in the USA has enacted a law called Unfair Competition Act which debars US-based companies to enter into any business deals with any foreign company using pirated versions of software or hardware. In such a scenario, compliance becomes one of the most strategic tools not only to retain the market share in the US, but also to gain edge against global competing players. This paper systematically explores the status of IT compliance in India vis-à-vis global players and suggests how different sectors may respond to early compliance benefits. The paper analyses the extent of new opportunity to Indian manufacturers emerging out of this law in comparison with its main competent suppliers in the US market.
\end{abstract}

\section{Keywords}

Trade Compliance, IT Compliance, Non-Tariff Barriers, Software Piracy, MSME, Unfair Competition Act

\section{Introduction}

Competitiveness globally is defined as the ability to innovate having reflections on productivity at all levels covering national, regional and enterprise capabili- 
ties which in turn is interlinked explained by the fact that the level of competitiveness of an economy is defined by the level of competitiveness of its enterprise whose productivity in turn depends upon the macro and industry ecosystem. All these three levels must be in synergy for achieving competitiveness in the international context. The European Commission (EC) defines competitiveness of enterprises as the "ability of firms to sustain and gain in market share through their cost and pricing policy, innovative use of production factors and updates to product characteristics.". Hence approaches to enterprise-level competitiveness can be divided into a macroeconomic perspective, a business strategy perspective, and a technology and innovation perspective. From the business strategy perspective of comparative competitiveness, a firm must be able to strategize effectively across the managerial domains of production, marketing, human resources and organization wherein technology becomes must to succeed [1] [2].

The development and use of technology also play a major role in determining patterns of international trade by affecting the comparative advantages of industrial sectors as witnessed by World Bank Investment Climate Surveys during 2003-06 which has brought forward the fact that firms that use ICT grow faster, invest more, and are more productive and profitable than those that do not. For example, sales growth is 3.4 percentage points higher among developing country firms that use e-mail to communicate with clients and suppliers (Table 1). Profits are substantially higher among firms using ICT.

New technologies also help compensate for possible disadvantages in the cost of capital and labor faced by firms. The IT services through their software and hardware have helped the manufacturing firms and countries to compete on varying degrees and at varying levels in product design, manufacturing, distribution, marketing etc. However, this perspective of technological innovations enhancing competitiveness can only remain durable and sustainable in light of stringent IPR protection.

Importance of Compliance through IPR protection tools becomes essential to ensure sustainable competitiveness in light of the growing incidence of noncompliance stated by the fact that even developed countries like the United States topped the list of digital piracy, accounting for 27.9 billion visits to piracy sites in 2017, followed by developing economies including Russia (20.6 billion), India (17 billion), Brazil (12.7 billion), Turkey (11.9 billion), Japan (10.6 billion), France (10.5 billion), Indonesia (10.4 billion), Germany (10.2 billion), and the U.K. (9.0 billion).

Table 1. Enhancing efficiency of manufacturing sector through IT interventions.

\begin{tabular}{cccc}
\hline & Non-IT user & IT user & Difference \\
\hline Sales growth & $0.40 \%$ & $3.80 \%$ & 3.4 \\
Employment Growth & $4.50 \%$ & $5.60 \%$ & 1.2 \\
Profitability & $4.20 \%$ & $9.30 \%$ & 5.1 \\
Total factor productivity (percent) & 78.2 & 79.2 & 1.0
\end{tabular}


Commercial value of unlicensed software in use by region includes Asia-Pacific with $\$ 19.1$ billion, Western Europe- $\$ 10.5$ billion, North America- $\$ 10.0$ billion, Latin America- $\$ 5.8$ billion and Middle East and Africa-\$3.7 billion. Additionally, it has been witnessed that international trade in counterfeit and pirated goods, augmented by forecasts of growth in import volumes and the ratio of customs seizures to real imports could reach $\$ 991$ billion; the value of domestically produced and consumed counterfeit and pirated goods could range from $\$ 524$ - $\$ 959$ billion and the value of digital piracy in movies, music and software could reach from $\$ 384$ - $\$ 856$ billion by 2022 [3]. Considering the abovementioned facts, maintaining the same level of competitiveness by intellectual property-owning companies/countries becomes questionable.

\section{Global Piracy: Violator of Theory of International Trade}

Rapid global economic integration has elevated the risks for intellectual property-owning companies. Fundamentally counterfeiting and piracy seem to act as a constraint on their ability to expand their sales in rapidly growing markets. Moreover, IPRs infringements also act as a direct competitive threat, as firms in labor-abundant countries copy the latest technologies and undermine what is perceived to be their remaining competitive edge. The cause of concern is when such productivity through increased illegal usage of IT results in cost competitive advantage in global markets.

In such a scenario there is obvious loss for manufacturers paying for information technology and compete with companies using pirated software. The international pricing and competitiveness of goods with the use of pirated software completely distorts the market and bring losses not only to the software makers but also to the genuine users of the software.

Software piracy permits the shadow diffusion of a software parallel to its legal diffusion in the marketplace, increasing its user base over time. Because of this software shadow diffusion, a software firm loses potential profits, access to a significant proportion of the software user base, opportunities for cross-selling, and marketing its other products and new generations of the software [4].

This goes against the basic international trade theory which assumes the absence of distortions in the prices of factors of production when the trading countries entered trade only due to the commodity price differences between themselves. This would mean that if some or one factor/s of production is highly priced or improperly priced by not being based on market demand and supply conditions, it is likely to create distortion in the market behavior [5]. This concern of price distortion has been seriously viewed by global organizations including WIPO, UNCTAD and other important international trade related bodies in the post WTO era.

Additionally, beyond just price distortions, rising piracy levels have shown a significant effect on the displacement of legitimate economic activity which is expected to increase by 1244 USD billion, estimated reduction in FDI by 231 
USD billion and finally impact of piracy on job market is reflected by an estimated net job losses to the tune of 4.2 to 5.4 million by 2022; through the displacement of legitimate economic activity by counterfeiting and piracy as indicated by the Economic Impacts of Counterfeiting and Piracy-Report prepared for BASCAP and INTA. It shows that the infiltration of counterfeit and pirated products, or IP theft, creates an enormous drain on the global economy-crowding out billions in legitimate economic activity and facilitating an "underground economy" that deprives governments of revenues for vital public services, forces higher burdens on tax payers, dislocates hundreds of thousands of legitimate jobs and exposes consumers to dangerous and ineffective products.

Taking cognizance of such a situation some states in the USA have enacted a law called Unfair Competition Act [6]. Under this act, a business that manufactures a product while using stolen or misappropriated information technology in its business operations engages in unfair competition when the product is sold in the USA, either separately or as a component of another product, in competition with a product made without use of stolen IT. A new cause of action allows private plaintiffs or the Attorney General to sue anyone who engages in this unfair competition, or to bring a claim against products made using stolen IT.

The basic objective of the act is to protect the rights and interests of those undertakings using lawful IT in their business operations by granting them the right to file unfair competition actions. The law applies regardless of whether the theft or misappropriation takes place inside the state or even inside the USA. i.e. if a company based in China engages in software piracy in China, the Washington law still affects the sale of goods inside the state and therefore impacts the business and compliance decision across the firms globally. Appreciating the fact that the USA traditionally has been a prominent market for Indian manufacturing exports with lesser piracy rates recorded as compared to other competing countries, technology compliance by Indian manufacturing companies is expected to give them competitive trade advantage in the USA in light of the UCA law.

\section{Compliance in International Trade}

Compliances in International Trade have evolved from quality issues (ISO 9001, Good Agricultural Practice [GAP], Good Manufacturing Practice [GMP], and so on) to environmental issues (ISO 14001, and so on) and are now moving towards social, labor, and equality areas (SA 8000, Fairtrade, and so on) and further to resource sustainability issues (Marine Stewardship Council [MSC], Forest Stewardship Council [FSC], carbon labeling, and so on). Such compliance by countries towards their international commitments has been widely investigated most by researchers using contextual approach like environment related commitment, IPR compliance commitments etc. [7].

Across these variety of traditional and emerging compliance measures globally, existing literatures have clear demarcations in their standpoint with few literatures pointing out the declining competitiveness of firms and nation as a whole due to enhanced cost of compliance, while on the other hand authors have 
welcomed the stringency of standards indicating its positive impact on innovation and thus competitiveness.

Carsten Fink [8] have argued on the economic rationales of these standards estimating the cost of compliance and its corresponding impact on trade flows and welfare effects. Jaffee [9], towards analyzing the impact of environmental compliance on the competitiveness of US manufacturing sector highlights the negative correlation between compliance and competitiveness due to cost escalation towards compliance leading to slow productivity and possibility of long term movement of manufacturing capacity from the less compliant countries in favor of the ones on higher pedestal of compliance in impacted sectors resulting into declining exports and increasing level of imports in those sectors. Henson and Jaffee [10] examined the impact that food safety standards in the context of international markets for high-value agricultural and food products have on developing countries. In addition to the economic costs, few literatures have also tried to highlight the social cost of compliance in the form of income distribution due to trade diversion from non-compliant sectors to compliant ones subsequently leading to high incidence of labor mobility from unskilled ones in non-compliance to trained and skilled ones.

On one hand where any type of trade compliance was considered as an economic burden on the stakeholders, there has been an equally interesting debate on the cost benefit analysis because of many literatures focusing on the benefits accruing to these companies where compliance actually was instrumental in achieving competitive advantage.

Henson and Jaffee [10] which earlier recognized that food standards can act as barriers to trade, also argued that the challenges posed by evolving standards can act as catalysts for the upgrading of food safety management capacity and the basis for competitive positioning in high-value markets.

Valeria and Mazzanti [11] have explored how the export competitiveness of the European Union has been positively affected by compliance with environmental regulation and innovation using theoretically based gravity model applied to the export dynamics of five aggregated manufacturing sectors classified by their technological or environmental content. Palmer et al. [12] also contended that stringent environmental measures induce innovative efforts leading to improvements in abatement and production technologies that offset the costs of the regulations drawing both on basic economic theory and existing data on control costs. Stefan [13] examines the key theoretical foundations and empirical evidence concerning the Porter Hypothesis, discusses its implications for the design of environmental regulations, and outlines directions for future research on the relationship between environmental regulation, innovation, and competitiveness.

Gugler [14], reviewed the traditional wisdom on the concept of strategic CSR developed in the North and the role that CSR engagement can play in corporate competitiveness. Ioanna Boulouta [15] also established significant positive link between corporate social responsibility (CSR) and competitiveness at the busi- 
ness level through an eclectic-synthetic framework of international economics and strategic management with a sample of 19 developed countries over a 6-year period. Wenbiao Li [16] probes into the significance of CSR to competitiveness of Chinese corporations.

Most of the literatures have also highlighted the rationale and economic impact of non-compliance. Fink [8] reviewed available empirical evidence on the economic impact of counterfeiting highlighting the aspect of cost of non-compliance. In light of growing incidence of non-compliance in technology arena resulting into high levels of software piracy, literatures in the technology compliance context have primarily discussed about factors leading to piracy and non-compliance.

Chatterjee et al. [17] investigated the phenomenon of unethical use of information technology (IT) showing that unethical IT use is primarily influenced by social (e.g., subjective norms), situational (e.g., moral intensity), and technological (e.g., technological facilitation) considerations. Rajeev and Nelson [18] also estimated the effects of economic, institutional and technical factors on the piracy of software and came out with a fact that a country's stage of development and the quality of governance have the largest impact on the incidence of software piracy. Antonio Rodríguez Andrés [19] investigated the extent to which income inequality influences national piracy rates across a sample of 34 countries. Banerjee and Khalid [20] argued that the piracy rate was influenced by expected benefits and costs to the pirates. A model was developed using a set of variables that may affect such benefits and costs and hence piracy rate in a country and tested for a large sample of 53 countries. Patrick [21] examined the relationship between intellectual property rights (IPRs) and the growth rate of per capita GDP during the period 1996-2006 in a sample 71 countries. Using software piracy data as a proxy for IPR violations, we find that countries with increasing rates of software piracy have lower growth rates.

Depken and Simmons [22] gave evidence that cross-country variation in software piracy was a combination of both traditional economic influences and institutional social mores and that software piracy rates were related to various economic variables. M. Limayem et al. [23] claimed that social factors and beliefs concerning consequences of software piracy have significant effects on software piracy intentions. Samuel [24], highlighted that the software protection strategy of software developer and the inherent risk to end user in using pirated software are two major factors that affect a user's decision on whether to purchase or pirate a software product. He analyzed the optimal protection strategy for software developer in horizontally and vertically differentiated markets.

While most of the study in the area of technology compliance focusses on rationale of piracy, economic losses of piracy to software creators in particular and country as a whole and cost of non-compliance, none of the study focusses on benefits of technology compliance brought in by the newly introduced law as Unfair Competition Act (UCA) in the USA having its impact on global value chain across manufacturing sectors [25] [26]. 


\section{Impact of UCA on India's Trade Competitiveness in the USA}

USA has traditionally been a prominent market for Indian manufacturing exports, yet Indian exporters have been finding it difficult to capitalize on this growing potential due to tough competition in the US with other competing suppliers like China, Saudi Arabia, Venezuela, Chinese Taipie, Ireland etc. Poor presence of India's manufacturing exports in the US as against other suppliers can be attributed to the following factors:

1) Regional Trade Agreements (RTAs) covering Mexico, Canada, Honduras as is seen in case of mineral fuel, automotive and pearl etc.

2) Preferential access in developed markets like the US, by virtue of its LDC status,

3) Better quality.

4) Better price competitiveness.

The rationale of trade and economic opportunities for Indian manufacturing exports emerging out of UCA compliance comes from the fact that it bars the US based companies/importers/traders to enter into any business deals with a foreign company using pirated versions of software or hardware. This has led to the shift in buying preferences of the importers in the US from giving weightage to quality, pricing, duties etc. to buying ONLY from countries where companies are IT compliant. This is expected to result into trade diversion of USA from existing trade partners with high piracy levels in favor of newer markets with better UCA compliance.

India is a signatory to global IPR regime and it has thus aligned its IPR Policies. This has resulted into comparatively better and fair use of information technology products in comparison to its competing countries like China, Vietnam and other countries from Southeast Asia where IPR regime is yet to evolve compared to the global standards. Appreciating India's strict IPR policies as compared to the countries which are supposedly giving competition to Indian manufacturing exports in the US market, UCA regime is expected to give Indian firms a better opportunity in the US.

This study therefore captures the implications of the law and analyzes the extent of new opportunity to Indian manufacturers and exporters emerging out of this law in comparison with its main competent suppliers in the US market. The study examines the benefits driven out of the rising uncertainties in the US market to the Indian exporters and manufacturers targeting the US.

Since the IT intensity varies from one manufacturing unit to another, across different processes i.e. marketing, production, design, distribution, finance etc. and so is the piracy rate and the awareness of this law, this trade impact is likely to vary across manufacturing sectors within the country. Therefore, the study describes the sector specific implications of this law.

Based on above discussions following research questions have been investigated in the present study: 
RQ1: Does IT Compliance regulation in the importing country provide scope of higher competitiveness to compliant firms of exporting countries in the short term?

RQ2: Does the benefit out of the UCA law goes equally to all those countries supplying to the US? If yes, where does Indian manufacturing sector stand? Which sectors will be more benefitted as compared to the others?

RQ3: Can this business opportunity be reaped equally by Indian manufacturers across all sectors? If not, which factors will drive this opportunity?

RQ4: Which of these sectors need policy attention on priority basis?

The Section 7.1 provides the country-level assessment thus addresses the first two research questions, whereas Section 7.2 deals with the sector-specific analysis thus answering the remaining two research questions. The result of the study is expected to benefit Indian exporters to the USA as well as the Indian Government by assisting them to chalk out their priority sectors for export and policy focus and accordingly drafting suitable policy interventions for facilitating UCA compliance by Indian industry to enable them to take first mover advantage in light of competing countries gearing up towards the same in the fear of losing market share in the US market. Therefore, considering that manufacturing sector accounts for a decent share of employability across sectors are we in the position to afford negligence to the UCA compliance leading to a big hit on country's foreign exchange earnings and thus the employment loss?"

\section{Conceptual Framework \& Methodological Tools}

In light of strict technological compliance in the USA, via implementation of the UCA law; buying preferences of the US importers seems to be shifting towards countries with lesser piracy rates. Better ranking of Indian firms on BSA piracy index, was expected to give Indian firms better competitiveness and business opportunity in the US market. In addition to piracy levels, there are following UCA benefit factors on which the success of UCA law across different manufacturing sectors depended on. These factors were also included in the questionnaire used for data collection from the exporters and other stakeholders (Section $6)$.

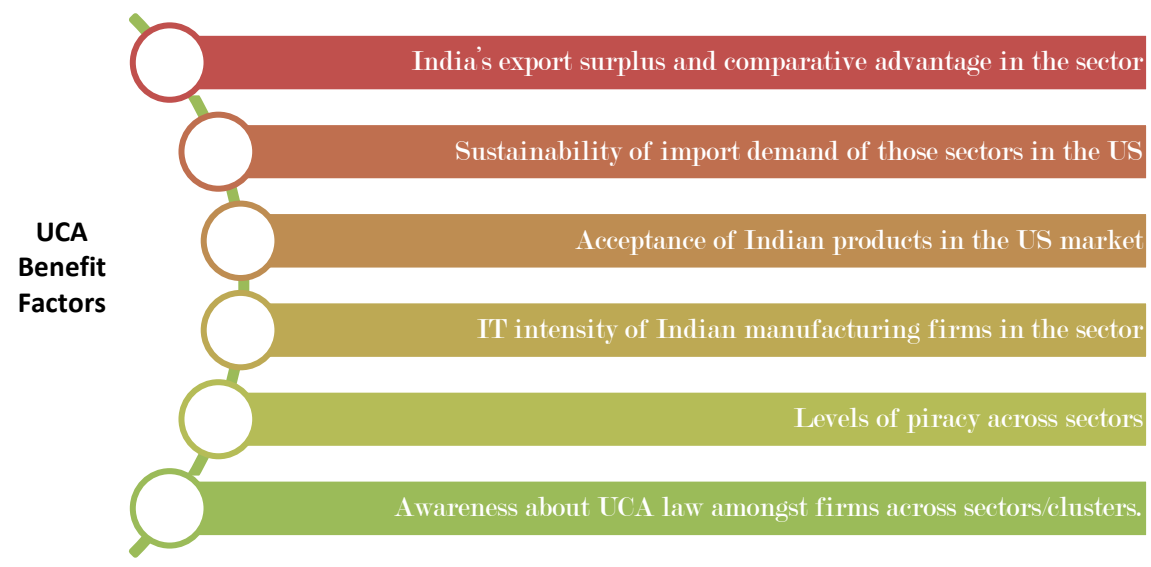


Since UCA law was specific to the US market, importance of the US market for Indian exporters was used as a first filter. To identify sectors of export importance in context to the US, two indicators were considered 1) percentage share of the US in total exports from India and 2) growth rate of exports in the US.

Next to ensure that shortlisted manufactured sectors (Table 2) have been found acceptable in the US market as against competing suppliers; an index termed Trade Intensity Index (TII) was estimated. The trade intensity statistic is the ratio of two export shares. The numerator is the share of the destination of interest in the exports of the region under study. The denominator is the share of the destination of interest in the exports of the world as a whole.

It can be measured as:

$$
\text { Trade Intensity Index }(\mathrm{TII}) \text { of IU }=\frac{\mathrm{TIU} / \mathrm{TIW}}{\mathrm{TWU} / \mathrm{TWW}}
$$

where

TII of IU = Trade Intensity Index to India to the USA

$\mathrm{TIU}=$ Trade volume of India to the USA

TIW $=$ Trade volume of India to World

TWU $=$ Trade volume of World to the USA

TWW $=$ Trade volume to world to world i.e. World total trade volume

TII takes a value between 0 and $+\infty$. Values greater than 1 indicate an "intense" trade relationship. We can think of the trade intensity index as a uniform export share. In other words, the statistic tells us whether or not a region exports more (as a percentage) to a given destination than the world does on average. It is interpreted in much the same way as an export share. It does not suffer from any "size" bias, so we can compare the statistic across regions, and over time when exports are growing rapidly. This indicator has been used to analyze the relative importance of India for the US and check the variation in the acceptance

Table 2. Quadrant analysis for sector identification.

\begin{tabular}{|c|c|c|}
\hline Quadrant & Description & Remarks/status \\
\hline Quadrant 1 & $\begin{array}{l}\text { Sectors which weren't } \\
\text { contributing much for India's } \\
\text { exports and also the US were not } \\
\text { a prime market. }\end{array}$ & $\begin{array}{l}\text { These sectors were taken off from analyzing } \\
\text { further since such sectors may not find its place } \\
\text { in the US market even if the IT compliance is } \\
\text { undertaken. }\end{array}$ \\
\hline Quadrant 2 & $\begin{array}{l}\text { These were sectors for which the } \\
\text { US has been a major market but } \\
\text { growth from India is poor or } \\
\text { nominal }\end{array}$ & $\begin{array}{l}\text { Since these are promising sectors in the US } \\
\text { market, possibility of India gaining better access } \\
\text { in the US if IT compliance is ensured in these } \\
\text { sectors. }\end{array}$ \\
\hline Quadrant 3 & $\begin{array}{l}\text { Sectors which are contributing } \\
\text { high for Indian exports but the } \\
\text { US is not the prime market. }\end{array}$ & $\begin{array}{l}\text { These sectors were taken off from analyzing } \\
\text { further since such sectors may not find its place } \\
\text { in the US market even if the IT compliance is } \\
\text { undertaken. }\end{array}$ \\
\hline Quadrant 4 & $\begin{array}{l}\text { These were the sectors important } \\
\text { for India as well the US being the } \\
\text { prime market }\end{array}$ & $\begin{array}{l}\text { Shortlisted for further analysis since IT } \\
\text { compliance becomes must to sustain this share } \\
\text { in the US market in the UCA regime. }\end{array}$ \\
\hline
\end{tabular}


levels of Indian imports across different sectors by the buyers in the US depicted with high index values [21].

However, it was assumed that this benefit would vary amongst the identified sectors due to the differences in their IT usage, IT cost in the total cost, piracy rate in India versus the competing countries, IT usage in competing countries, awareness about UCA law and IPR enforcement in the competing countries. The factors listed in UCA benefit drove the decision of impacting the extent of business opportunity incurred by a sector as per the UCA law. Few independent variables depicting positive impact would extend an opportunity to the sector under UCA regime, while few others depicting negative impact demonstrates threat. These independent variables certainly varied from one manufacturing sector to another, the combined effect of these variables would also vary bringing more benefits to some sectors as compared to the others. These factors therefore acted as independent variables towards developing a statistical model of UCA benefit index as per the following research hypothesis:

Ho: There is no significant difference in the opportunity emerged out of UCA across sectors

\section{Hi: There is significant difference in the opportunity}

Since the statistical assumptions of equal variance of ANOVA were getting violated, an alternative robust variance (Welch) test was applied to check the level of significance. Results were indicative of significant difference in levels of opportunity and threat across the sectors.

\section{Data Collection}

Towards capturing information on above mentioned data points, this paper has taken a mixed methodology approach. Quantitative aspects on trade data both for Indian exports as well as the US imports, country wise piracy levels, and ICT usage involved secondary data collection; while sector specific IT intensity, piracy levels and UCA awareness involved rigorous primary survey. Primary survey covered 219 respondents across 15 sectors. Purposive sampling was used to select the state clusters representing sectors having export competitiveness globally as well as in the US and simultaneously depicting high import growth in the US guaranteeing the scope for Indian exporters.

Respondents were primarily divided into four categories (Table 3): 1) Exporters since these will be the main affected party, 2) Manufacturers or the suppliers of the raw material 3) Officials from the Export promotion Councils of the included sectors and 4) Finally, the lawyers to have a legal perspective towards the Intellectual Property Rights (IPR) enforcement. The sectors included auto components, gems and jewelry, chemicals, textiles, electrical and electronics, leather and engineering goods. Amongst these sectors, highest respondents were from textile sector (26\%) followed by auto components (13\%), Iron and steel (12\%), Leather and Gems (6\% - 7\%). Few respondents were also from other sectors including plastics, rubber, stone (construction material), metal products and pharmaceuticals. 
Table 3. Range defined for independent variables.

\begin{tabular}{|c|c|c|c|c|c|c|}
\hline & \multirow{2}{*}{ Variable } & \multicolumn{4}{|c|}{ Range } & \multirow{2}{*}{$\begin{array}{l}\text { Impact } \\
\text { +ve/-ve }\end{array}$} \\
\hline & & Very high & High & Nominal & Low & \\
\hline 1. & No. of Computers in a company ${ }^{a}$ & $<200$ & $100 \%-200$ & $50 \%-100$ & $5 \%-50$ & + \\
\hline 2. & Piracy rate in India ${ }^{a}$ & $<10 \%$ & $5 \%-10 \%$ & $1 \%-5 \%$ & $1 \%$ & - \\
\hline 3. & ICT usage in competing country ${ }^{\mathrm{b}}$ & \multicolumn{2}{|c|}{ Higher than India } & \multicolumn{2}{|c|}{ Lower than India } & - \\
\hline 4. & Piracy rate in competing countryc & \multicolumn{2}{|c|}{ Higher than India } & \multicolumn{2}{|c|}{ Lower than India } & + \\
\hline 5. & India's share in US imports ${ }^{\mathrm{d}}$ & $<10 \%$ & $5 \%-10 \%$ & $1 \%-5 \%$ & $>1 \%$ & + \\
\hline 6. & Awareness about UCA in India ${ }^{a}$ & & es & No & & + \\
\hline \multicolumn{7}{|c|}{ Sources: } \\
\hline a & \multicolumn{6}{|c|}{$\begin{array}{l}\text { These data points are the perceptions of the respondents captured through the primary survey } \\
\text { at pan Indian level across different manufacturing sectors. }\end{array}$} \\
\hline b & \multicolumn{6}{|c|}{$\begin{array}{l}\text { "Beñat Bilbao-Osorio, Soumitra Dutta, and Bruno Lanvin", 2018, The Global Information } \\
\text { Technology Report }{ }^{1} \text {, World Economic Forum. }\end{array}$} \\
\hline c & \multicolumn{6}{|c|}{ Global Piracy Study, 2018, Business Software Alliance ${ }^{2}$} \\
\hline d & \multicolumn{6}{|c|}{ Author's estimation using data from Trade $\mathrm{Map}^{3}, 2018$, International Trade Centre, Geneva } \\
\hline
\end{tabular}

\section{Results and Discussion}

\subsection{UCA Benefit: India versus Competing Suppliers in the US}

It is evident that the UCA law may bring forth a change in the level of acceptance of Indian manufactured goods in the US against the similar goods originating from countries with poor compliance levels. The very first question therefore was to find out to what extent and against which countries/products does this opportunity exist. For this a cross country analysis of the piracy levels vis-à-vis their import share of manufactured goods in the US was conducted.

Figure 1 indicates competitive position of Indian manufactured goods in the US vis-à-vis other existing competing suppliers. Four prominent players in the US manufacturing imports stand out to be China, Canada, Mexico and Japan. Other minor players with somewhat equivalent shares as that of India included Korean Rp, Saudi Arabia, and Venezuela etc. While Russia, Brazil and some South East Asian economies including, Thailand, Vietnam, Philippines and Malaysia along with Middle Eastern \& African nations of Iraq, Israel and Nigeria are currently lagging behind India but may speed up in times to come.

${ }^{1}$ The Global Information Technology Report 2018 is a project within the framework of the World Economic Forum's Global Competitiveness and Benchmarking Network and the Industry Partnership Program for Information and Communication Technologies featuring the latest overview of the current state of ICT readiness in the world.

${ }^{2} \mathrm{BSA} \mid$ The Software Alliance is the foremost organization dedicated to promoting a safe and legal digital world. The BSA Global Software Piracy Study quantifies the volume and value of unlicensed software installed on personal computers in a given year. The study involves collecting 182 discrete data inputs and assessing PC and software trends in each of 116 markets.

${ }^{3}$ Trade Map, a database from International Trade Centre in Geneva; provides users with indicators on export performance, international demand, alternative markets and the role of competitors covering 220 countries and territories and 5300 products of the Harmonized System. 
Share in United States of America's imports (\%)

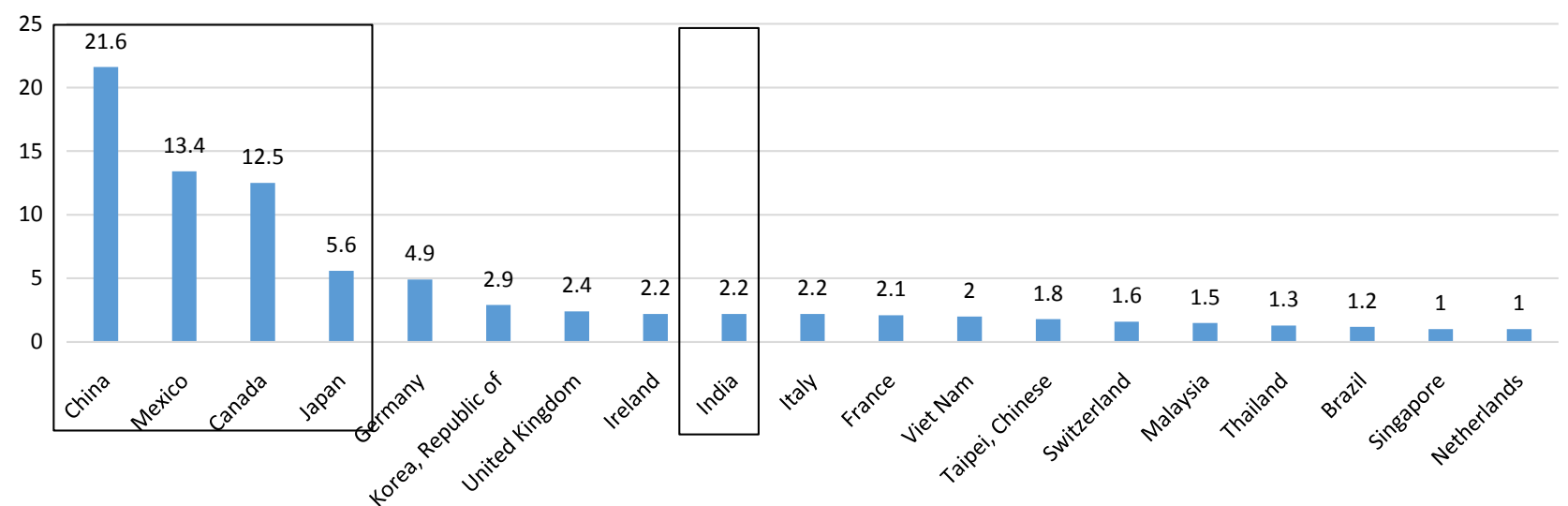

Figure 1. Import share of countries in total US imports of manufactured goods. Source: Author's analysis based on ITC database (2018).

Considering that UCA law has resulted into shifting priorities of the importers from all other prominent factors like pricing, trading agreements, quality, and standards to only IT compliance, a clear advantage to Indian exporters of the manufactured goods goes against countries where the import shares in the US market is low paralleled with high rates of piracy. This brings us to four scenarios of opportunity/threats for India vis-à-vis other suppliers to the US (Table 4):

Figure 2 demonstrates a matrix which brings forth the emerging opportunity for India in the sectors/product lines currently supplied by Philippines, Indonesia, Vietnam, Nigeria, Iraq, Thailand and Russia since India already enjoys a better share in the US imports as compared to these countries. A higher piracy rates in these countries will give an additional benefit to India.

However, for countries including China and Venezuela which have a better share in the US but also their piracy rates being higher in these countries than India, there is an expected shift of the preferences of US buyers for India. While lower piracy rates and higher share gives advantage to India, at the same time an opposite scenario extends threat to Indian manufacturing exports. This would mean competition for Indian manufacturing exporters is likely to become stricter in sectors currently supplied by Canada, Mexico, Japan, Korea, Saudi Arabia and UK.

\subsection{Identification of Sectors/Products Benefitting in UCA Context}

A broad country wise analysis provided reflections of India's stand as against other global players in the US. However, the advantage/disadvantage for India against these players would vary from one country to another depending on the product lines in which these players are operating in the US. For instance, China, Bangladesh and Vietnam compete with India for textiles; Mexico, Israel and Belgium for gems and jewelry; Ireland, China, Canada for Organic Chemicals and China and Mexico for electronics. Therefore, specific manufactured products 
Table 4. Opportunity vs. threat implications post UCA compliance.

\begin{tabular}{|c|c|c|c|}
\hline \multirow{2}{*}{ Scenario } & \multicolumn{2}{|c|}{ Competing Country Status } & \multirow{2}{*}{$\begin{array}{l}\text { UCA impact for India } \\
\text { (opportunity versus threat) }\end{array}$} \\
\hline & Import share & Piracy rate & \\
\hline (i) & Low & High & Maximum opportunity \\
\hline (ii) & High & High & Emerging opportunity \\
\hline (iii) & High & Low & Maximum threat \\
\hline (iv) & Low & Low & Moderate threat \\
\hline
\end{tabular}

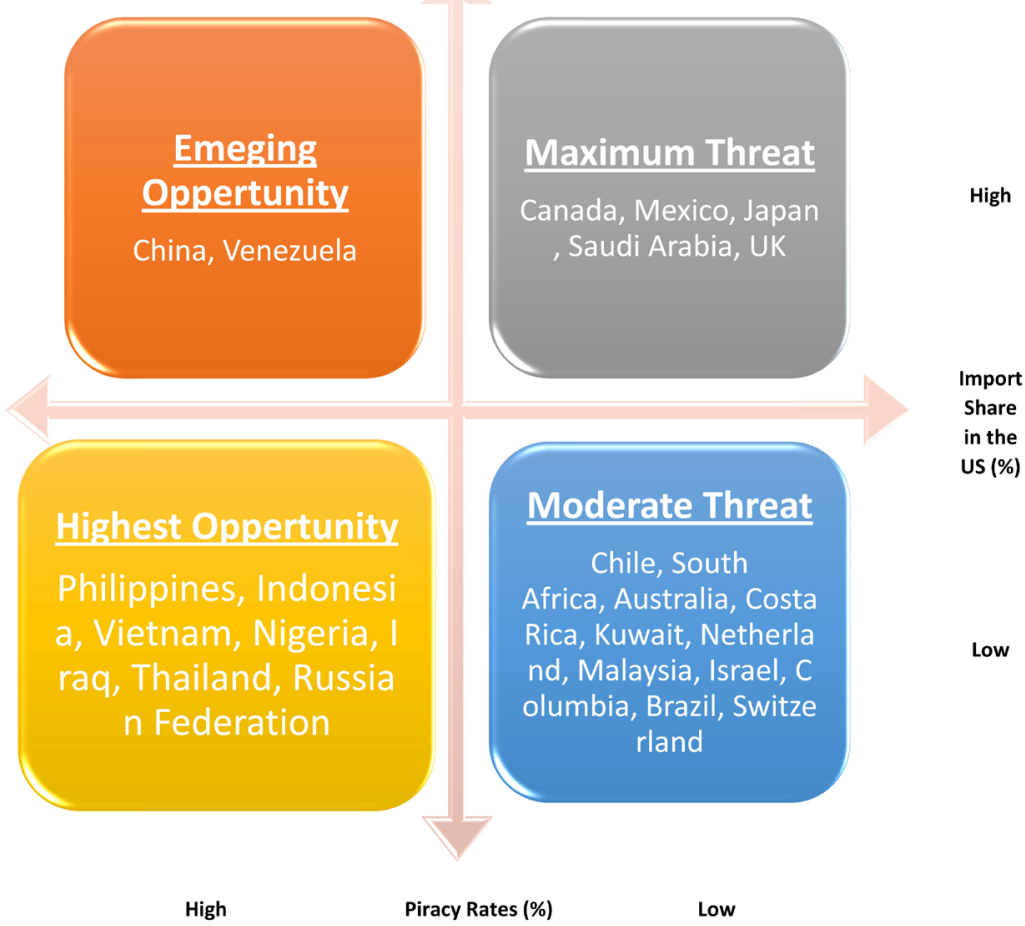

Figure 2. Opportunity versus threat for India in UCA context: Cross country analysis.

from India which would gain/loose in the US would depend on many other factors like 1) capability of India to supply i.e. evaluation of manufacturing sectors of export importance with comparative advantage 2) share of USA in total exports from India indicating selling preference of Indian companies to the USA. The quadrant analysis hence brings out clear demarcation of sectors on these two criterions.

Sectors falling in quadrant 2 and 4 (Figure 3) were taken for further analysis with a rationale that IT compliance on priority would extend trade benefit to Indian manufacturers in this sector since these sectors witnessed high export growth from India with the US as our major trading partner indicating seller's preference of these sectors for the USA.

This sector selection further carried trade advantage in case the selling preference of Indian companies coincided with the buying preference of the US importers which was checked by estimation of Trade competitive index termed as 


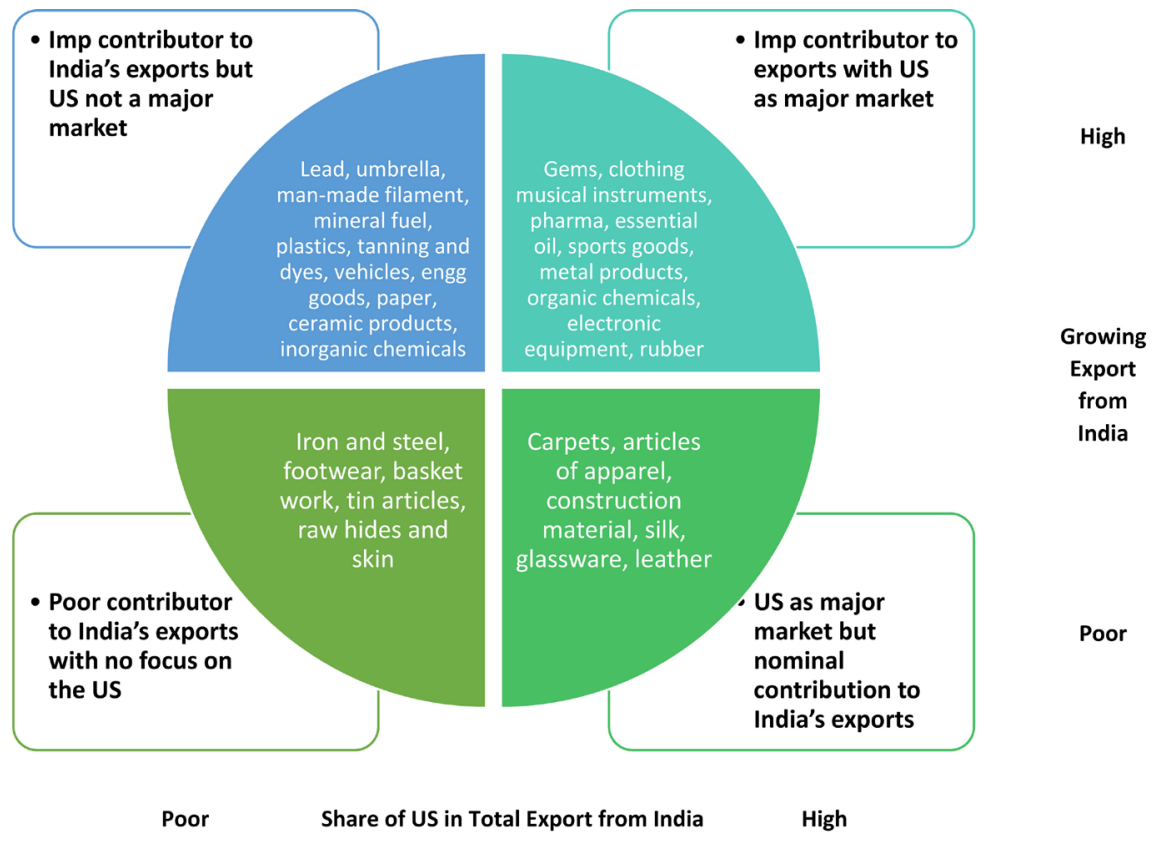

Figure 3. Sectoral analysis. Source: Author's analysis based on ITC Trade database 2018.

"Trade Intensity Index" (TII). High values of India's TII with the USA meant high buying preference of the US buyers in favor of India. Hence the sectors in quadrant 2 and 4 from above table having high TII values brought us closer to take UCA benefit.

TII values as estimated in Table 5 clearly indicates that the UCA benefit will certainly be incurred by the sectors including gems and jewelry with highest TII value of approximately 6 , followed by tanning and dyeing. Similar was the case for plastics, footwear and engineering goods. Our trade strength with the US as compared to the other competing suppliers was also found appreciable for woven yarns, essential oils, pharma etc. Hence these sectors have been picked up for further analysis.

Specific manufactured products from India which would gain/loose in the US would finally depend on many other factors like awareness about UCA law across different manufacturing exporters in India; and finally, IT usage and piracy levels in India versus competing countries. The paper finally dwells upon these considerations to identify specific products through a UCA benefit index.

UCA benefit index as depicted in Table 6 highlights that for gems and jewelry and tanning, dyeing extracts and auto components, all the competing countries have high IT intensity and lower piracy rates. Hence Indian gems and jewelry sector must look forward towards enhancement of IT intensity and UCA enforcement at a much faster rate to have its presence in the US market. While on the other hand UCA benefit seems to be felt highest in case of leather, worn clothing, woven yarn, articles of apparel (knit or crochet), plastics, metal, footwear, rubber, electronics, engineering and glassware considering higher piracy rates in almost all the existing supplier to the US. 
Table 5. Acceptance of Indian manufactured goods in the US: TII values.

\begin{tabular}{|c|c|c|c|c|c|c|}
\hline HS Code & Product & 2014 & 2015 & 2016 & 2017 & 2018 \\
\hline '71 & Gems and Jewelry & 5.86 & 5.25 & 8.17 & 5.75 & 5.96 \\
\hline '32 & Tanning, dyeing extracts & 5.35 & 5.83 & 4.40 & 4.65 & 4.25 \\
\hline '63 & Worn clothing & 3.03 & 2.78 & 2.18 & 2.27 & 2.44 \\
\hline '38 & Miscellaneous chemical products & 2.20 & 2.35 & 2.05 & 2.10 & 1.79 \\
\hline '29 & Organic chemicals & 2.06 & 1.87 & 1.42 & 1.63 & 1.54 \\
\hline '42 & Leather & 1.81 & 1.90 & 1.54 & 1.27 & 1.36 \\
\hline '56 & Woven yarns & 1.10 & 1.20 & 1.14 & 1.36 & 1.34 \\
\hline '33 & Essential oils & 1.16 & 1.19 & 1.11 & 1.01 & 1.07 \\
\hline '61 & Articles of apparel (knit or crochet) & 1.52 & 1.42 & 1.39 & 1.06 & 1.06 \\
\hline '39 & Plastics & 1.08 & 0.95 & 0.73 & 0.91 & 1.04 \\
\hline '30 & Pharma & 1.14 & 1.20 & 0.84 & 0.91 & 0.99 \\
\hline '82 & Metal & 0.99 & 1.03 & 0.72 & 0.76 & 0.84 \\
\hline '64 & Footwear & 1.01 & 0.98 & 0.76 & 0.69 & 0.70 \\
\hline '40 & Rubber & 0.90 & 0.98 & 0.71 & 0.68 & 0.70 \\
\hline '59 & Laminated textile fabric & 0.83 & 0.73 & 0.56 & 0.69 & 0.56 \\
\hline '85 & Electrical, electronic equipment & 0.27 & 0.35 & 0.41 & 0.31 & 0.33 \\
\hline '84 & Engineering goods & 0.35 & 0.40 & 0.32 & 0.30 & 0.29 \\
\hline '90 & Optical medical apparatus & 0.23 & 0.24 & 0.23 & 0.22 & 0.21 \\
\hline '66 & Umbrellas & 0.04 & 0.03 & 0.03 & 0.03 & 0.02 \\
\hline
\end{tabular}

Source: Author's analysis on the basis of ITC 2018.

On the other hand, India will be able to reap benefits of UCA only if IT compliance is ensured in leather, essential oils and footwear industry followed by metal, textiles, engineering goods and chemicals considering that high piracy prevalence may act as deterrent towards our export growth into the US.

Moreover considering, higher IT usage in almost all the competing countries across sectors in question India needs to expedite its IT applications in these sectors. Currently, levels of ICT adoption in India have been found ranging from medium to low. Most of the IT adoptions if found high were in applications dealing into finance typically reported in case of auto components, chemicals, gems and metal. While auto industry has been seen using IT majorly in finance, design and production; chemicals have been found using it in ERP applications as well.

It is pretty clear by now that the factors listed above certainly drives the decision of impacting the extent of business opportunity incurred by a sector as per the UCA law. These independent variables certainly varied from one manufacturing sector to another. For this purpose, an opportunity-threat potential assessment was done based on the stakeholders' perspective. About 150 subject-matter experts were approached and requested to answer these two questions: 
Table 6. Analyzing role of piracy and IT usage towards UCA.

\begin{tabular}{|c|c|c|c|}
\hline Sectors & $\begin{array}{l}\text { UCA advantage to India } \\
\text { due to higher piracy for products } \\
\text { with high TII with the US }\end{array}$ & $\begin{array}{l}\text { UCA disadvantage } \\
\text { due to high Piracy } \\
\text { rate in India }\end{array}$ & $\begin{array}{l}\text { UCA disadvantage due to } \\
\text { high IT usage in competing countries }\end{array}$ \\
\hline Gems and Jewelry & $\begin{array}{l}\text { Very tough since piracy levels } \\
\text { lesser than India in all }\end{array}$ & & Very tough all countries have better IT usage. \\
\hline Tanning, dyeing extracts & Moderate (except China all compliant) & & Very tough all countries have better IT usage. \\
\hline Worn clothing & Very high & Moderate & $\begin{array}{l}\text { High (against Vietnam, Indonesia, Honduras and } \\
\text { Cambodia) }\end{array}$ \\
\hline Miscellaneous chemical & Lesser & Moderate & Moderate \\
\hline Organic chemicals & Lesser & Moderate & Moderate \\
\hline Leather & Highest (China maximum share) & High & Moderate (against Vietnam) \\
\hline Woven yarns & Advantage against all & Moderate & $\begin{array}{l}\text { High (against Vietnam, Indonesia, Honduras and } \\
\text { Cambodia) }\end{array}$ \\
\hline Essential oils & Lesser & High & Moderate \\
\hline $\begin{array}{l}\text { Articles of apparel } \\
\text { (knit or crochet) }\end{array}$ & Advantage against all & Moderate & $\begin{array}{l}\text { High (against Vietnam, Indonesia, Honduras and } \\
\text { Cambodia) }\end{array}$ \\
\hline Plastics & Very high & Moderate & Very tough all countries have better IT usage. \\
\hline Pharma & $\begin{array}{l}\text { Very tough since piracy } \\
\text { levels lesser than India in all }\end{array}$ & Low & Very tough all countries have better IT usage. \\
\hline Metal & Very high (against China and Taiwan) & Moderate & Very tough all countries have better IT usage. \\
\hline Footwear & $\begin{array}{l}\text { Very high (against China, Vietnam and } \\
\text { Indonesia) }\end{array}$ & High & Moderate (against Vietnam \& Indonesia) \\
\hline Rubber & $\begin{array}{l}\text { Very high (against China, } \\
\text { Vietnam and Thailand) }\end{array}$ & Low & Very tough all countries have better IT usage. \\
\hline Laminated textile fabric & Lesser & Moderate & Very tough all countries have better IT usage. \\
\hline Electrical, electronic equipment & Very high (against China and Taiwan) & Low & Very tough all countries have better IT usage. \\
\hline Engineering goods & Very high (against China) & Moderate & Very tough all countries have better IT usage. \\
\hline Glassware & High (against China) & Low & Very tough all countries have better IT usage. \\
\hline Auto components & $\begin{array}{c}\text { Very tough since piracy levels lesser than } \\
\text { India in all }\end{array}$ & Low & Very tough all countries have better IT usage. \\
\hline
\end{tabular}

Source: Author's compilation from various sources.

$A$ : Of the following 11 -sector rank them based on their opportunities potential in bi-lateral trade with USA under UCA regime?

$B:$ Of the following 11-sector rank them based on their threat potential in bi-lateral trade with USA under UCA regime?

Following Table 7 shows the average rank of the manufacturing sector from 150 respondents.

As can be seen in the chart above, under UCA regime, chemical, electrical, electronics, and engineering could be more beneficiary sector than others provided all compliance are made before competing countries. Automobiles, Iron/steel, and textiles forecasted have mediocre opportunity as well as threat 
Table 7. Opportunity versus threat for Indian manufacturing sectors under UCA.

\begin{tabular}{|c|c|c|c|c|}
\hline & Industry & Mean & St. deviation & Std. error \\
\hline \multirow{11}{*}{$\begin{array}{c}\text { Opportunity } \\
\text { Potential }\end{array}$} & Auto & 6.92 & 1.55 & 0.31 \\
\hline & Chemical & 10.79 & 1.369 & 0.366 \\
\hline & Electrical & 8.25 & 1.983 & 0.496 \\
\hline & Electronics & 9.33 & 1.589 & 0.41 \\
\hline & Engineering & 8.14 & 1.703 & 0.455 \\
\hline & Gems & 8 & 1.183 & 0.357 \\
\hline & Glassware & 7.3 & 0.483 & 0.153 \\
\hline & Iron and steel & 7.14 & 1.39 & 0.296 \\
\hline & Leather & 5.17 & 0.637 & 0.13 \\
\hline & Other & 7.45 & 2.605 & 0.583 \\
\hline & Textiles & 6.65 & 1.082 & 0.156 \\
\hline \multirow{11}{*}{$\begin{array}{c}\text { Threat } \\
\text { Potential }\end{array}$} & Auto & 7.32 & 1.464 & 0.293 \\
\hline & Chemical & 8.93 & 0.997 & 0.267 \\
\hline & Electrical & 8.69 & 2.024 & 0.506 \\
\hline & Electronics & 7.93 & 0.458 & 0.118 \\
\hline & Engineering & 8.07 & 0.616 & 0.165 \\
\hline & Gems & 6.73 & 1.009 & 0.304 \\
\hline & Glassware & 6.3 & 0.483 & 0.153 \\
\hline & Iron and steel & 7.27 & 1.162 & 0.248 \\
\hline & Leather & 7.79 & 1.693 & 0.346 \\
\hline & Other & 7.55 & 1.82 & 0.407 \\
\hline & Textiles & 7.21 & 1.352 & 0.195 \\
\hline
\end{tabular}

potential subject to within industry compliance alertness. Leather industry is expected to suffer most under UCA regime. This would highlight the dominance of unfair trade practices in the sector. Glassware sector is projected to have positive demand from its import partner provided technological and software compliances are as per trading country norms.

Welch's ANOVA test has been opted as compared to classic ANOVA test. Welch's analysis of variance provides critical benefits and protections because you can use it even when your groups have unequal variances. Since the mean value against each industry represents multiple phenomena, and which differ in terms of their opportunity and threat potential. So, as variance of these mean scores is expected to vary across industries, the Welch's ANOVA test has been opted for the mean-comparison analysis. The results are as follows (Table 8).

Scatter diagram representing the opportunity versus threat across sectors in question indicated following combinations (Others include: metal, pharma, plastic, rubber and stone): (Figure 4). 
Table 8. Robust tests of equality of means.

\begin{tabular}{cccccc}
\hline & & Statistic $^{\mathrm{a}}$ & df1 & df2 & Sig. \\
\hline $\begin{array}{c}\text { Opportunity } \\
\text { Potential }\end{array}$ & Welch & 32.769 & 10 & 66.496 & 0.000 \\
& Brown-Forsythe & 16.895 & 10 & 117.695 & 0.000 \\
$\begin{array}{c}\text { Threat } \\
\text { Potential }\end{array}$ & Welch & 12.136 & 10 & 68.981 & 0.000 \\
& Brown-Forsythe & 5.202 & 10 & 126.949 & 0.000 \\
\hline
\end{tabular}

aAsymptotically F distributed.

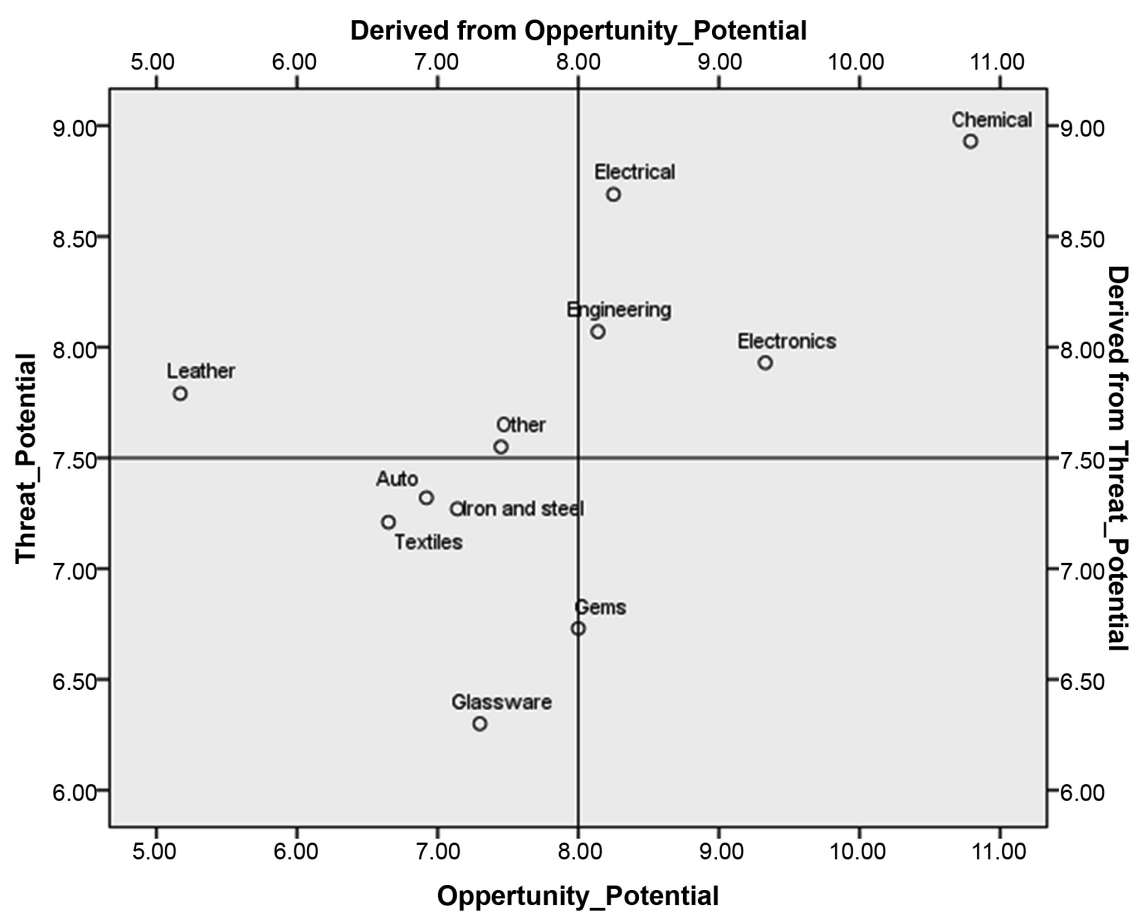

Figure 4. Sector-wise trade opportunity vs. threat assessment.

\section{Discussion and Conclusion}

Government of India highlights the vision and mission to make India one of the largest exporters of manufactured goods by raising India's exports share from present $2.0 \%$ in 2016 to $3.5 \%$ by 2020 , thus making India major player among low cost countries (LCCs). With MSMEs constituting 95\% this sector was expected to make huge contribution towards this target. However, this sector has still to cope-up towards this expectation as the share of Indian MSME to US export has witnessed a fall from $89.1 \%$ to $64.2 \%$ in the last two years. While compliance related to labor, environment and quality have been quite prevalent across the globe; Information technology compliance is becoming the prime concern for importers, is one of India's prime export markets of the US wherein US buyers could be barred from doing business with non-compliant global suppliers using pirated versions of software and hardware in the form of UCA.

Unfair Competition Act (UCA) comes as a boon at a time when global marketers have been witnessing the unfair international pricing and competitiveness 
of goods with the use of pirated software; and due to this cost-imbalance it brings losses not only to the software makers but also to the genuine users of the software. Moreover, this also seemed to be going against the global competitiveness of goods with the use of pirated software which completely distorts the market. Appreciating that this was against the basic international trade theory which assumes the absence of distortions in the prices of factors of production when the trading countries entered trade only due to the commodity price differences between themselves, UCA law ensured strict technological compliance for US importers barring them to do business with any foreign exporters using pirated software.

As this gave rise to shift in buying priorities of US buyers towards countries with less or no piracy, the present study contends that Indian manufacturing exporters stand a fortunate chance to enhance their competitiveness through technological compliance as per the US market requirements i.e. quick and timely adherence to the copyrighted technologies and related softwares/programs. As results suggest, certain Indian MSME industries like chemicals, textiles, leather and gems and jewelry are already doing good and also well poised to capitalize on the opportunities provided under UCA regime. Seriousness of the UCA compliance is clearly reflected by the efforts taken by more almost all competing countries towards reducing their piracy levels.

One of limitations of the present study is that the lack of a post-hoc pair wise test for sectors was done to check the significance between each pair of sectors. Since certain sectors did not have enough data to run the post-hoc tests. Future studies should address this concern to get the statistical validation of the finally reproduced set of sector-specific manufacturing products which would gain in the light of the new UCA law.

\section{Conflicts of Interest}

The authors declare no conflicts of interest regarding the publication of this paper.

\section{References}

[1] Wignaraja, G. (2002) Competitiveness Strategy in Developing Countries: A Manual for Policy Analysis. Routledge, London. https://doi.org/10.4324/9780203466032

[2] Özçelik, E. and Taymaz, E. (2004) Does Innovativeness Matter for International Competitiveness in Developing Countries?: The Case of Turkish Manufacturing Industries. Research Policy, 33, 409-424. https://doi.org/10.1016/j.respol.2003.09.011

[3] BASCAP (Business Action to Stop Counterfeiting and Piracy) and The International Trademark Association (INTA) (2017) The Economic Impacts of Counterfeiting And Piracy. Frontier Economics.

[4] Givon, M., Mahajan, V. and Muller, E. (1995) Software Piracy: Estimation of Lost Sales and the Impact on Software Diffusion. Journal of Marketing, 59, 29-37. https://doi.org/10.1177/002224299505900103

[5] Fernandez, R.N., Ribeiro, F.G. and Duarte, J.M.D.P. (2018) Effects of Software Pi- 
racy on Economic Growth. International Journal of Economics and Finance, 10, 1-11. https://doi.org/10.5539/ijef.v10n6p1

[6] http://apps.leg.wa.gov/rcw/default.aspx?cite=19.330

[7] Thomas, K. (2017) The Concept of "Compliance". In: Assessing Intellectual Property Compliance in Contemporary China, Palgrave Macmillan, Singapore, 25-42. https://doi.org/10.1007/978-981-10-3072-7_2

[8] Fink, C. (2008) Enforcing Intellectual Property Rights: An Economic Perspective. International Centre for Trade and Sustainable Development (ICTSD).

[9] Jaffe, A.B., Peterson, S.R., Portney, P.R. and Stavins, R.N. (1995) Environmental Regulation and the Competitiveness of U.S. Manufacturing: What Does the Evidence Tell Us? Journal of Economic Literature, 33, 132-163. https://www.jstor.org/stable/2728912

[10] Henson, S. and Jaffee, S. (2006) Food Safety Standards and Trade: Enhancing Competitiveness and Avoiding Exclusion of Developing Countries. The European Journal of Development Research, 18, 593-621. https://doi.org/10.1080/09578810601070753

[11] Valeria, C. and Massimiliano, M. (2012) On the Green and Innovative Side of Trade Competitiveness? The Impact of Environmental Policies and Innovation on EU Exports. Research Policy, 41, 132-153. https://doi.org/10.1016/j.respol.2011.08.004

[12] Karen, P., Oates, W.E. and Portney, P.R. (1995) Tightening Environmental Standards: The Benefit-Cost or the No-Cost Paradigm? Journal of Economic Perspectives, 9, 119-132. https://doi.org/10.1257/jep.9.4.119

[13] Ambec, S., Cohen, M.A., Elgie, S. and Lanoie, P. (2013) The Porter Hypothesis at 20: Can Environmental Regulation Enhance Innovation and Competitiveness? Review of Environmental Economics and Policy, 7, 2-22. https://doi.org/10.1093/reep/res016

[14] Gugler, P. and Shi, J.Y.J. (2009) Corporate Social Responsibility for Developing Country Multinational Corporations: Lost War in Pertaining Global Competitiveness? Journal of Business Ethics, 87, 3-24. https://doi.org/10.1007/s10551-008-9801-5

[15] Boulouta, I. and Pitelis, C.N. (2014) Who Needs CSR? The Impact of Corporate Social Responsibility on National Competitiveness. Journal of Business Ethics, 119, 349-364. https://doi.org/10.1007/s10551-013-1633-2

[16] Li, W.B. (2012) Study on the Relationships between Corporate Social Responsibility and Corporate International Competitiveness. Energy Procedia, 17, 567-572. https://doi.org/10.1016/j.egypro.2012.02.137

[17] Chatterjee, S., Valacich, J.S. and Sarker, S. (2012) Unethical Use of Information Technology: A Two-Country Study. 2012 45 th Hawaii International Conference on System Sciences, Maui, HI, 4-7 January 2012, 3071-3080. https://doi.org/10.1109/HICSS.2012.621

[18] Goel, R.K. and Nelson, M.A. (2009) Determinants of Software Piracy: Economics, Institutions, and Technology. The Journal of Technology Transfer, 34, 637-658. https://doi.org/10.1007/s10961-009-9119-1

[19] Andrés, A.R. (2006) Software Piracy and Income Inequality. Applied Economics Letters, 13, 101-105. https://doi.org/10.1080/13504850500390374

[20] Banerjee, D., Khalid, A.M. and Sturm, J.-E. (2005) Socio-Economic Development and Software Piracy: An Empirical Assessment. Applied Economics, 37, 2091-2097. https://doi.org/10.1080/00036840500293276 
[21] Le, Q. and McLennan, P. (2011) The Effects of Intellectual Property Rights Violations on Economic Growth. Modern Economy, 2, 107-113.

https://doi.org/10.4236/me.2011.22015

http://www.SciRP.org/journal/me

[22] Depken, C.A. and Simmons, L.C. (2004) Social Construct and the Propensity for Software Piracy. Applied Economics Letters, 11, 97-100. https://doi.org/10.1080/1350485042000200187

[23] Limayem, M., Khalifa, M. and Chin, W.W. (2004) Factors Motivating Software Piracy: A Longitudinal Study. IEEE Transactions on Engineering Management, 51, 414-425. https://doi.org/10.1109/TEM.2004.835087

[24] Kin Kwan, S.S., Jaisingh, J. and Tam, K.Y. (2008) Risk of Using Pirated Software and Its Impact on Software Protection Strategies. Decision Support Systems, 45, 504-516. https://doi.org/10.1016/j.dss.2007.06.014

[25] Bezmen, T.L. and Depken, C.A. (2006) Influences on Software Piracy: Evidence from the Various United States. Economics Letters, 90, 356-361.

https://doi.org/10.1016/j.econlet.2005.08.029

[26] Žigić, K. (1998) Intellectual Property Rights Violations and Spillovers in North-South Trade. European Economic Review, 42, 1779-1799.

https://doi.org/10.1016/S0014-2921(97)00098-6

\section{Data Sources}

- Trade Map, a database from International Trade Centre, 2018

- The Global Information Technology Report 2018

- Global Piracy Report 2017 by Business Software Alliance (BSA)

- World Development Indicators 2018. 